\title{
Axonal Transport of Activating Transcription Factor-2 Is Modulated by Nerve Growth Factor in Nociceptive Neurons
}

\author{
Jean-Dominique Delcroix, ${ }^{1}$ Sharon Averill, ${ }^{2}$ Karin Fernandes, ${ }^{1}$ David R. Tomlinson, ${ }^{1}$ John V. Priestley, ${ }^{2}$ and \\ Paul Fernyhough 1 \\ 1Division of Neuroscience, School of Biological Sciences, University of Manchester, Manchester M13 9PT, United \\ Kingdom, and 2Neuroscience Section, Division of Biomedical Sciences, St. Bartholomew's and The Royal London School \\ of Medicine and Dentistry, Queen Mary and Westfield College, University of London, London E1 4NS, United Kingdom
}

\begin{abstract}
The aim of this study was to determine whether axonal transport of activating transcription factor-2 (ATF2) occurs in adult sensory neurons, and whether this process is under neurotrophin control. Antisera to both total ATF2 and to the activated (i.e., phosphorylated) form were used for immunocytochemistry and Western blotting. ATF2 was localized to predominantly nociceptive dorsal root ganglion cells in adult rats and shown to accumulate proximal and distal to a sciatic nerve ligature as a result of axonal transport. Subcutaneous injection of nerve growth factor (NGF) decreased the levels of fast retrograde axonal transport of activated ATF2 by $97 \%(p<0.05)$ and elevated levels of retrograde axonal transport of total ATF2 by twofold $(p<0.02)$. In contrast, blocking endogenous NGF
\end{abstract}

Nerve growth factor (NGF) signals, initially, through binding to the high-affinity trkA receptor on nerve endings of nociceptive sensory neurons, with an undefined involvement of the lowaffinity ${\text { p } 75^{\text {NTR }}}$ receptor (Chao and Hempstead, 1995; Kaplan and Miller, 1997). Ligand and receptor are then internalized and retrogradely transported down the axon to the cell body (Ehlers et al., 1995). Studies show that neurotrophins can induce rapid elevations in tyrosine phosphorylation of trk receptors that are propagated in a retrograde fashion along axons. These events may be mediated via fast axonal transport of the trk receptor-ligand complex but may also involve an undefined process traveling at speeds in excess of those seen for fast axonal transport (Ehlers et al., 1995; Bhattacharyya et al., 1997; Senger and Campenot, 1997). Second messengers downstream from trk receptors, such as $\mathrm{G}$ proteins, extracellular signal-regulated kinase (ERK), and phospholipase C- $\gamma$ (PLC- $\gamma$ ), undergo fast retrograde axonal transport, but the significance of this is unknown (Johansson et al., 1995).

It has been proposed that neurons may also be capable of axonal transport of transcription factors (Schmied et al., 1993; Curtis and DiStefano, 1994; O'Neill and Kaltschmidt, 1997). The immunocytochemical localization of ELK-1, cAMP response el-

\footnotetext{
Received March 4, 1999; revised July 14, 1999; accepted July 16, 1999.

This work was supported by the Wellcome Trust (P.F. and D.R.T.), the Medical Research Council (J.V.P.), and the British Diabetic Association (J.-D.D.). We thank Drs. L. F. Reichardt and D. O. Clary for the trkA antibody.

Drs. Delcroix and Averill share equal first authorship.

Correspondence should be addressed to Dr. Paul Fernyhough, School of Biological Sciences, 1.124 Stopford Building, University of Manchester, Oxford Road, Manchester M13 9PT, UK; or Prof. John Priestley, Neuroscience Section, Division of Biomedical Sciences, Queen Mary and Westfield College, Mile End Road, London E1 4NS, UK.

Copyright (C) 1999 Society for Neuroscience 0270-6474/99/190001-07\$05.00/0
}

using an anti-NGF antibody induced an elevation in retrograde axonal transport of activated ATF2 of 4.5 -fold $(p<0.05)$ and decreased retrograde axonal transport of total ATF2 by $72 \%$ $(p<0.05)$. NGF or anti-NGF treatment had no effect on the anterograde transport levels of total or activated ATF2. This study shows that signaling by target-derived NGF to the cell bodies of sensory neurons consists, in part, of the modulation of levels and activation status of a retrogradely transported transcription factor, ATF2.

Key words: adult rat; dorsal root ganglion; nerve growth factors; neurotrophin; phosphorylation; sciatic nerve; sensory neuron; signal transduction ement binding protein (CREB), and $\mathrm{NF} \kappa \mathrm{B}$ to axon terminals and dendrites in the CNS would support such a notion (O'Neill and Kaltschmidt, 1997; Crino et al., 1998; Sgambato et al., 1998). Studies in Aplysia have shown that a nuclear localization signal (NLS) can be recognized by the retrograde transport-nuclear import pathway that conveys proteins along the axon to the soma and into the nucleus (Schmied et al., 1993). In fact, a protein homologous to the transcription factor $\mathrm{NF} \kappa \mathrm{B}$ and expressing the NLS is found in axons of Aplysia (Povelones et al., 1997), and homologous NLS motifs are present within the basic region of the DNA binding domain of the activating transcription factor (ATF) family of transcription factors (Hai et al., 1989).

NGF maintains the phenotype of a subpopulation of nociceptive sensory neurons in adult vertebrates, in part, through the regulation of neuropeptide expression (Snider and McMahon, 1998). NGF-dependent modulation of substance $P$ and calcitonin gene-related peptide (CGRP) expression is mediated through the interaction of transcription factors with, for example, the cAMP response element (CRE) and the AP-1 binding sites (Quinn et al.,

This article is published in The Journal of Neuroscience, Rapid Communications Section, which publishes brief, peerreviewed papers online, not in print. Rapid Communications are posted online approximately one month earlier than they would appear if printed. They are listed in the Table of Contents of the next open issue of JNeurosci. Cite this article as: JNeurosci, 1999, 0:RC24 (1-7). The publication date is the date of posting online at www.jneurosci.org.

http://www.jneurosci.org/cgi/content/full/3457 
1995). Transcription factors that interact with these sites include CREB and c-jun, which are activated through phosphorylation by the mitogen-activated protein kinases (MAPKs) which include ERK, c-jun N-terminal protein kinase (JNK), and p38 (Whitmarsh and Davis, 1996). At promoter sites of other genes, ATF-2 binds to the CRE and can heterodimerize with c-jun to form functional AP-1 complexes (Su and Karin, 1996; Whitmarsh and Davis, 1996). The activation and subsequent DNA binding of ATF2 are regulated by phosphorylation, which is also under the control of the MAPKs (Whitmarsh and Davis, 1996). In PC12 cells NGF signals in a ras-dependent manner to activate ERK (Bonni and Greenberg, 1997), JNK (Minden et al., 1994), and p38 (Xing et al., 1998). Conversely, with depletion of NGF in embryonic sympathetic neurons and primed PC12 cells there is also activation of JNK (Xia et al., 1995; Virdee et al., 1997; Eilers et al., 1998) and p38 (PC12 cells only) (Xia et al., 1995). These latter events are stress-related and result in apoptosis.

Because ATF2 has an NLS motif, and is also linked with NGF signaling, we determined to study the effects of NGF on the expression and axonal transport of ATF2 in adult sensory neurons in vivo.

\section{MATERIALS AND METHODS}

Animal treatments. Adult male Wistar rats (250-300 gm) were treated by systemic subcutaneous injection $(10 \times 10 \mu \mathrm{l}$ amounts $)$ at multiple sites into the hindlimb under halothane-induced anesthesia with (1) saline, (2) $1.0 \mathrm{mg} / \mathrm{kg}$ human recombinant NGF, (3) a total of $10 \mu \mathrm{g}$ of control $\mathrm{IgG}$, or (4) a total of $10 \mu \mathrm{g}$ of monoclonal anti-NGF IgG (clone 27/21; Boehringer Mannheim, Mannheim, Germany). At 6 hr after injection the animals were again anesthetized, the left flank was opened, and double ligatures, $1 \mathrm{~cm}$ apart, were applied to the sciatic nerve at midthigh level (Delcroix et al., 1997). In antibody-treated rats, the animals had a second antibody injection, $6 \mathrm{hr}$ after the first. At $12 \mathrm{hr}$ after placement of the nerve ligatures the animals were either killed by a blow to the head and exsanguinated or anesthetized under pentobarbital and perfusion-fixed with $4 \%$ paraformaldehyde (Priestley, 1997).

Histology. Sections from $\mathrm{L}_{4}$ and $\mathrm{L}_{5}$ dorsal root ganglia (from untreated rats only) and midsciatic nerve (ligatured and unligatured) were stained using indirect immunofluorescence histochemistry with antibodies directed against both forms of (i.e., total) ATF2 (New England Biolabs, Beverley, MA; 1:50 dilution) and against phosphorylated ATF2 (New England Biolabs; phosphorylated on Thr-71; 1:100 dilution) (Priestley, 1997). Other immunoreagents included sheep anti-CGRP (Affiniti Research Products, Maidenhead, Exeter, UK; 1:800 dilution), mouse antiS100 $\beta$ (1:2000 dilution), mouse anti-200 kDa neurofilament (clone N52; Sigma, St. Louis, MO; 1:800 dilution), and biotinylated Griffonia simplicifolia IB4 lectin (Sigma; $10 \mathrm{mg} / \mathrm{ml}$ dilution) and were detected as previously described (Averill et al., 1995). Double or triple labeling of ATF2 together with CGRP, IB4, or S100 $\beta$ was achieved using standard indirect immunofluorescence techniques with tetramethyl rhodamine, FITC, and aminomethylcoumarin-labeled secondary antisera. Preparations were viewed on a Leica (Nussloch, Germany) DMRB epifluorescence microscope using Y3, L4, and A filter blocks. Photographs were taken using a Hamamatsu (Hamamatsu City, Japan) C4742-95 digital camera, and plates were assembled using Adobe Photoshop (Adobe Systems, Mountain View, CA).

Quantification of ATF2 axonal transport. The proximal (for anterograde transport) and distal (for retrograde transport) and intermediate nerve segments (all of $0.3 \mathrm{~cm}$ length) were homogenized using a Polytron (Kinematica, Lucerne, Switzerland) in 0.1 mM PIPES, pH 6.9, $5.0 \mathrm{~mm}$ $\mathrm{MgCl}_{2}, 5.0 \mathrm{~mm}$ EGTA, $0.5 \%$ Triton X-100, $20 \%$ glycerol, $1.0 \mathrm{~mm}$ phenylmethylsulfonyl fluoride, and a mixture of protease inhibitors. SDSPAGE ( $8 \%$ acrylamide) was performed on $10 \mu \mathrm{g}$ of total protein, and the separated proteins were transferred to nitrocellulose (enhanced chemiluminescence membrane; Amersham, Buckinghamshire, UK) using a graphite blotter. A polyclonal anti-trkA RTA antibody (a gift from Drs. L. F. Reichardt and D. O. Clary, University of California, San Francisco, CA) and the ATF2 antibodies described above were used. Detection on film was achieved using the phototope-HRP system (New England Biolabs). The relative levels of protein were determined by laser scanning of the film, and the total pixel intensity for each band was captured using Molecular Analyst software (Bio-Rad, Hercules, CA). Values were then adjusted for any uneven loading by measuring the levels of total protein on the blot by india ink staining (also measured using laser scanning).

\section{RESULTS}

\section{Expression of ATF2 in lumbar dorsal root ganglia}

Nociceptive neurons can be divided into two subpopulations: NGF-dependent neurons, which are immunoreactive for CGRP or trkA; and glial cell line-derived neurotrophic factor (GDNF)dependent neurons, which are immunoreactive for RET and IB4 (Averill et al., 1995; Bennett et al., 1998). Immunoreactivity for total (data not shown) and phosphorylated ATF2 was detected in lumbar dorsal root ganglion (DRG) cells, with small and mediumsized cells most intensely stained (Fig. 1a,c). The phosphorylated ATF2 immunoreactivity was primarily cytoplasmic, but in addition most DRG cells showed a characteristic granular labeling in the nucleus (Fig. 1). Such staining has been reported previously using this antibody and may represent either nonspecific immunoreactivity or compartmentalized basal expression (Walton et al., 1998).

Double- and triple-labeling analysis for phosphorylated ATF2 revealed cytoplasmic immunoreactivity in both the trkA/CGRP and the RET/IB4 subpopulations (Fig. $1 a-d$ ), with most phosphorylated ATF2-immunoreactive cells labeled for either CGRP or IB4 (Fig. 1e-g). In contrast, double labeling with a large cell marker (N52, $200 \mathrm{kDa}$ neurofilament) confirmed that large cells showed either no cytoplamic immunoreactivity, or only light immunoreactivity, for phosphorylated ATF2 (results not shown).

\section{Expression and axonal transport of ATF2 in sciatic nerve}

Phosphorylated ATF2 was detected in axons of the intact sciatic nerve (data not shown), and immunostaining was also performed on sciatic nerve subjected to a double ligature. Immunoreactivity for phosphorylated (Fig. $2 a, b$ ) and total (data not shown) ATF2 was present both proximal and distal to the ligatures, indicative of fast anterograde and retrograde axonal transport. There was evidence of colocalization of CGRP with phosphorylated ATF2 (Fig. $2 c, d$ ). In contrast, the ATF2-immunoreactive structures did not show staining for $\mathrm{S} 100 \beta$ (a Schwann cell marker), confirming that the immunoreactivity for phosphorylated ATF2 is predominantly axonal (Fig. $2 e-g$ ). The intermediate nerve segment showed very low levels of staining (Fig. $2 a, b$ ), suggesting that most of the phosphorylated ATF2 detected was derived from axonal transport (similar results were seen for total ATF2).

\section{Effect of NGF on the levels of axonal transport of ATF2}

The accumulations of ATF2 proximal and distal to a sciatic ligature were examined by Western blotting. ATF2 species of 77 and $69 \mathrm{kDa}$ were detected (Fig. 3). The $77 \mathrm{kDa}$ species corresponds to full-length ATF2 protein, and the $69 \mathrm{kDa}$ species is a truncated isoform generated by alternative splicing (Georgopoulos et al., 1992). NGF treatment induced a 92\% elevation $(p<$ 0.02 ) in retrograde axonal transport of the $77 \mathrm{kDa}$ form of total ATF2 but significantly diminished transport of the $77 \mathrm{kDa}$ form of phosphorylated ATF2 $(p<0.02)$ (Table 1$)$. Anti-NGF antibody treatment reduced retrograde transport of total ATF2 by $72 \%(p<0.05)$ and elevated transport of phosphorylated ATF2 by $62 \%$. Adjusting the levels of phosphorylated ATF2 to the total levels of ATF2 protein revealed that anti-NGF treatment elevated the levels of phosphorylated ATF2 by 4.5 -fold $(p<0.05)$ (Table 

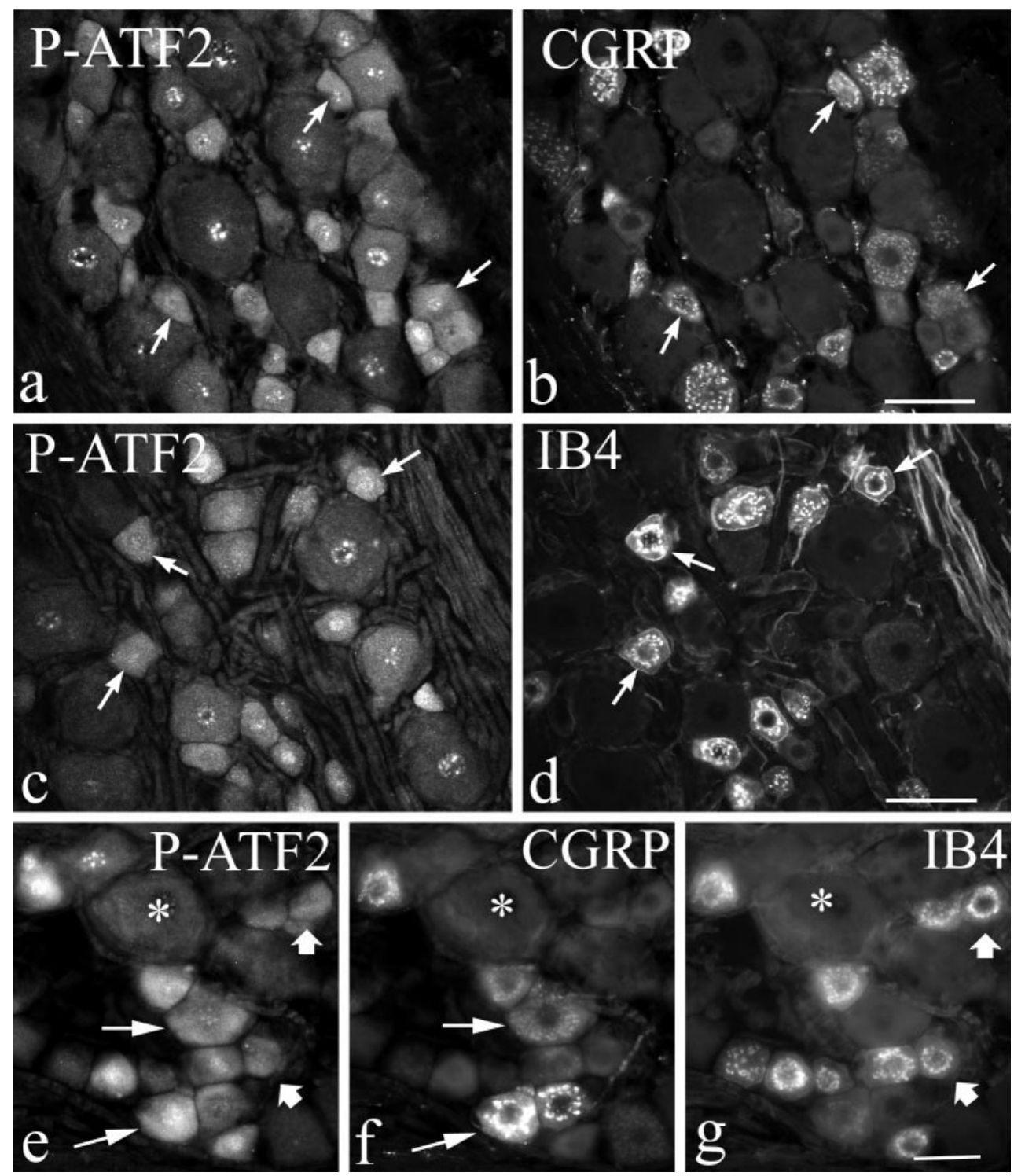

Figure 1. Immunofluorescence double $(a-d)$ and triple $(e-g)$ labeling for the phosphorylated form of ATF2 (P-ATF2) and CGRP and/or IB4 in lumbar dorsal root ganglia. P-ATF2 immunoreactivity is strongest in small to medium-sized cells $(a-d)$ and show that these include both the CGRP and IB4 subpopulations. Arrows indicate double-labeled cells. Note that the P-ATF2 immunoreactivity is primarily cytoplasmic, but most cells also show some nuclear staining. Triple labeling $(e-g)$ shows that the CGRP and IB4 subpopulations account for almost all the P-ATF2-immunoreactive small cells. Long arrows indicate P-ATF2 and CGRP double-labeled cells; short arrows indicate P-ATF2 and IB4 double-labeled cells. Some P-ATF2-immunoreactive cells express both CGRP and IB4. In contrast, the asterisk indicates a large cell that has only background levels of P-ATF2 immunoreactivity and is negative for both CGRP and IB4. Scale bars: $a-d, 50 \mu \mathrm{m}$; $e-g, 25 \mu \mathrm{m}$.
1, last column). There was no effect of NGF or anti-NGF treatment on the levels of retrograde axonal transport of trkA (Table 1). Finally, the rates of accumulation of phosphorylated and total ATF2 were $\sim 1.0 \mu \mathrm{m} / \mathrm{sec}(3.6 \mathrm{~mm} / \mathrm{hr})$ and were linear for up to 12 $\mathrm{hr}$ and the same as measured for trkA, strongly indicative of fast axonal transport (which can operate at velocities of 0.7-2.0 $\mu \mathrm{m} / \mathrm{sec}$ ) (Fig. 4).

\section{DISCUSSION}

Our results reveal several new aspects of NGF neurobiology in sensory neurons. This is the first demonstration that a transcription factor involved in NGF signaling, namely ATF2, is enriched in nociceptive DRG cells. This study also shows for the first time in vertebrate neurons that a transcription factor, ATF2, in an activated (phosphorylated) form can be conveyed from nerve ending to soma, and vice versa, by fast axonal transport. Finally, we have shown that the levels of retrograde axonal transport of ATF2 are under NGF-dependent modulatory control.

\section{Mechanisms of neurotrophin-regulated signal propagation along axons}

Neurotrophins transmit signals along axons by a variety of mechanisms, and these can be classified according to their rate of propagation. The fastest process $(>20 \mu \mathrm{m} / \mathrm{sec})$ may involve the neurotrophin-dependent modulation of $\mathrm{Ca}^{2+}$ mobilization from the endoplasmic reticulum (Finkbeiner et al., 1997). Next in speed are processes that probably involve a cascade of rapid tyrosine phosphorylation events in the absence of trk receptor transport (Senger and Campenot, 1997). For example, brainderived neurotrophic factor can alter the levels of tyrosine phosphorylation of the trkB receptor at rates of $\sim 8 \mu \mathrm{m} / \mathrm{sec}$ within the sciatic nerve (Bhattacharyya et al., 1997). Similar results have been demonstrated for NGF-dependent modulation of trkA tyrosine phosphorylation in compartmented cultures of sympathetic neurons (Senger and Campenot, 1997). All other suggested mechanisms of neurotrophin signal propagation are likely to involve fast vesicular axonal transport at rates of $0.7-2 \mu \mathrm{m} / \mathrm{sec}$. 

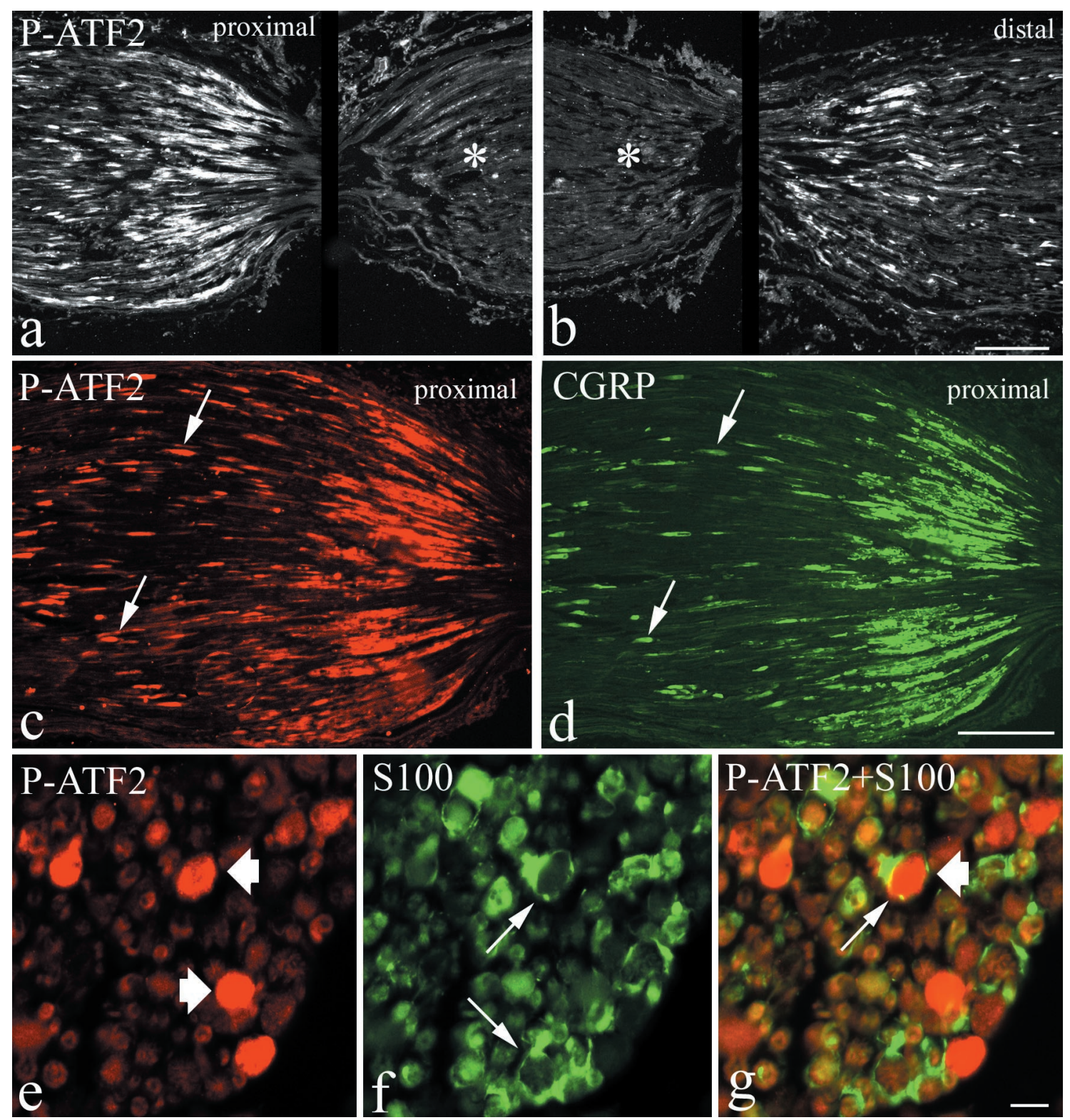

Figure 2. Accumulation of immunoreactivity for phosphorylated ATF2 (P-ATF2) occurs both proximal $(a)$ and distal $(b)$ to a double ligature of the sciatic nerve. The two ligatures were $1 \mathrm{~cm}$ apart, but only the regions directly adjoining the ligatures are illustrated. Note that immunoreactivity is present at only low levels in this interligature portion $(a, b$, asterisks $) . c, d$, Double labeling shows that P-ATF2 immunoreactivity proximal to a sciatic ligature occurs in CGRP-immunoreactive axons. Arrows indicate double-labeled fibers. $e-g$, Double labeling shows the relationship between P-ATF2 and S100 $\beta$ immunoreactivities in a transverse section proximal to a ligature. Short arrows indicate P-ATF2 immunoreactivity in transversely cut axons; long arrows show S100 $\beta$ immunoreactivity in Schwann cells. In the merged image $(g)$ an S100 $\beta$-immunoreactive Schwann cell can be seen to envelop a P-ATF2-immunoreactive axon. Scale bars: $a-d, 200 \mu \mathrm{m} ; e-g, 10 \mu \mathrm{m}$.

For example, NGF-dependent modulation of trkA tyrosine phosphorylation has been observed in the sciatic nerve and proceeded at rates that are consistent with axonal transport of the receptor (Ehlers et al., 1995). The data presented in this study show that the transcription factor ATF2 can now be added to the group of molecules that use axonal transport as part of neurotrophin signaling.

\section{NGF-dependent mobilization of ATF2 in the axon}

Although the axonal transport that we have observed is novel, there are several possible mechanisms that could account for axonal transport of ATF2. Binding of NGF to trkA induces internalization of the ligand-receptor complex as part of an endosomal vesicle, which is sent retrogradely possibly through interaction with a motor protein, such as dynein (Curtis and DiStefano, 1994). NGF binding to trkA is known to trigger the association of ERK and PLC- $\gamma 1$ with the trkA-NGF receptorligand complex (Vetter et al., 1991; Loeb et al., 1992), and so the endosomal vesicle will presumably comprise a complex of trkA combined with these and other proteins. It is therefore possible that transcription factors such as ATF2 are also transported as part of a trkA-ligand-enzyme complex. In addition, it is possible that transcription factors associate directly with microtubuledirected motor proteins. For example, in yeast the regulatory subunit $\mathrm{I} \kappa \mathrm{B} \alpha$ of $\mathrm{NF} \kappa \mathrm{B}$ binds directly to a cytoskeletal protein, 
(a) phospho-ATF2

(b) total ATF2

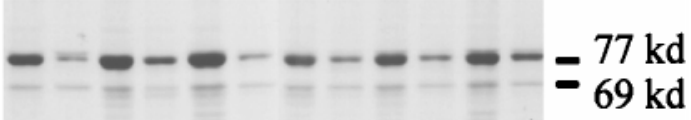

$\begin{array}{lllllllllllll}\text { Lanes } & 1 & 2 & 3 & 4 & 5 & 6 & 7 & 8 & 9 & 10 & 11 & 12\end{array}$ control IgG anti-NGF

\section{(c) phospho-ATF2}

(d) total ATF2
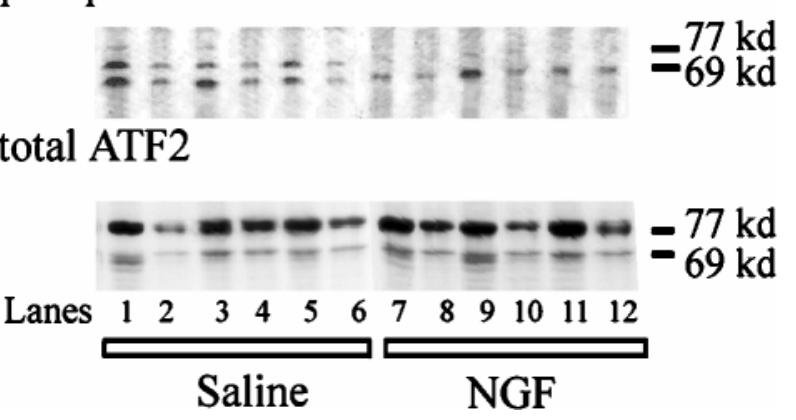

Figure 3. Western blots showing effect of anti-NGF antibody and NGF treatment on levels of fast retrograde axonal transport of ATF2. $a, b$, Phosphorylated ATF2 $(a)$ and total ATF2 $(b)$ for NGF antibody study. Lanes 1-6, Control antibody (nonspecific IgG) treated; lanes 7-12, antiNGF antibody treated. $c, d$, Phosphorylated ATF2 $(c)$ and total ATF2 $(d)$ for NGF treatment study. Lanes 1-6, Control saline treated; lanes 7-12, NGF treated. Within each group the results from three separate animals are shown. Odd numbered lanes are the retrograde accumulation; the following even numbers are the corresponding intermediate nerve segment (local production and/or transport between crush sites). Note the NGF-induced disappearance of the $77 \mathrm{kDa}$ species of phospho-ATF2 in $c$.

Dlc-1, which is homologous to the human $9 \mathrm{kDa}$ outer-arm dynein light-chain protein (Crepieux et al., 1997). It is also possible that transcription factors are axonally transported associated with their upstream MAPK. Thus JNK, one of the MAPKs that binds and phosphorylates ATF2, is found associated with a member of the kinesin superfamily of proteins at microtubules (Nagata et al., 1998). JNK is localized to axons (Fernyhough et al., 1999), and we have recently shown that it is axonally transported (Averill et al., 1998). JNK and ATF2 may therefore form a complex and be transported together.

NGF increased the levels of retrograde but not anterograde transport of total ATF2. The increase in ATF2 may have been caused by the mobilization of ATF2 stored within the nerve ending or may have arisen from de novo local synthesis. Although mRNA has not been reported in sensory axons, this possibility is not without precedent. mRNA has been localized to dendrites of CNS neurons (Crino and Eberwine, 1996), and an RNA-binding protein, Staufen, is thought to be responsible for the dendritic transport (Kiebler et al., 1999). mRNA has also recently been localized to axons of sympathetic (Olink-Coux and Hollenbeck, 1996) and hypothalamic neurosecretory (Trembleau et al., 1996) neurons, and mRNA for the transcription factor CREB has been detected in a synaptosomal preparation from the developing brain (Crino et al., 1998).

\section{Modes of NGF-regulated activation of ATF2}

NGF modulated the levels of retrograde axonal transport of phosphorylated ATF2 (Fig. 3, Table 1). ATF2 is phosphorylated, and hence activated, by the MAPKs (Whitmarsh and Davis, 1996). Two of the best characterized MAPKs for which ATF2 is a substrate are p38 kinase and JNK. We and others (Giasson and Mushynski, 1997; Eilers et al., 1998) have failed to detect p38 kinase activity in peripheral neurons. In contrast, JNK occurs in DRG cells similar to those that express ATF2 and is also axonally transported (Fernyhough et al., 1999; our unpublished results). It is therefore tempting to suggest that $\mathrm{JNK}$ is responsible for the regulation of ATF2 phosphorylation that we observe. However, ERK (Livingstone et al., 1995) or another kinase of unknown identity and under NGF-dependent regulation could be involved. NGF decreased and anti-NGF increased the levels of phosphorylated ATF2 that were retrogradely transported. This suggests that reduced NGF-dependent occupancy of trkA and/or p $75^{\text {NTR }}$ may be linked to activation of MAPK and hence ATF2. This type of activation is known to occur with JNK. Removal of NGF from primed PC12 cells (Xia et al., 1995) or embryonic sympathetic neurons (Deshmukh and Johnson, 1997; Virdee et al., 1997; Eilers et al., 1998) induces activation of JNK and subsequent apoptosis. Lack of occupancy of p75 ${ }^{\mathrm{NTR}}$ in embryonic sensory neurons leads to apoptosis (Rabizadeh et al., 1993), and in other cells types apoptotic functions for $\mathrm{p} 75^{\mathrm{NTR}}$ have been linked to activation of JNK (Casaccia-Bonnefil et al., 1996; Kaplan and Miller, 1997). Thus, in the absence of NGF the $\mathrm{p} 75^{\mathrm{NTR}}$ receptor may be unoccupied or bound by other neurotrophins (Dechant and Barde, 1997; Kaplan and Miller, 1997), with a subsequent activation of a MAPK and phosphorylation of ATF2.

\section{Functional implications of NGF modulation of axonal transport of ATF2}

The localization of ATF2 to the CGRP/trkA-expressing population of DRG cells (Fig. 1) is additional evidence of an important

Table 1 Effect of NGF and anti-NGF treatment on axonal transport of ATF2

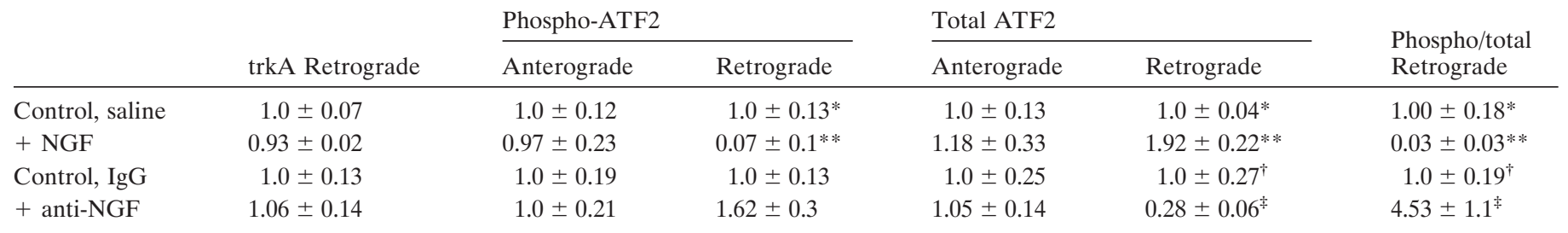

Double ligatures were applied to the left midsciatic nerve for $12 \mathrm{~h}$, and the left hindlimb of adult rats was treated with saline, NGF, control IgG antibody, or anti-NGF antibody.

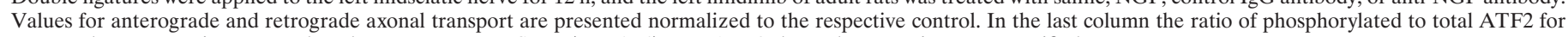
retrograde transport is presented. Values are means \pm SEM $(n=3-4)$. For ATF2 the $77 \mathrm{kDa}$ species was quantified.

${ }^{*}$ vs ${ }^{* *} p<0.02 ;{ }^{\dagger}$ vs ${ }^{\ddagger} p<0.05(t$ test $)$, for control, saline vs NGF treated or control, IgG vs anti-NGF treated. 


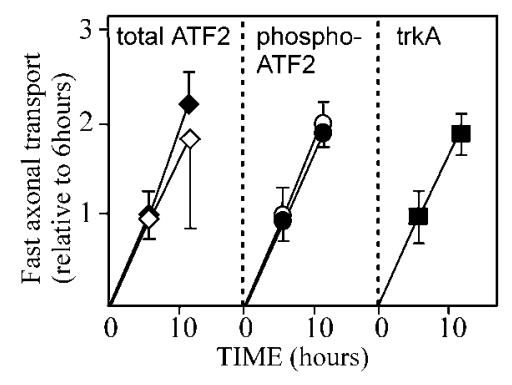

Figure 4. ATF2 accumulates in a linear fashion and with a velocity characteristic of fast axonal transport. Double ligatures were applied to the sciatic nerve for 6 and $12 \mathrm{hr}$, and levels of accumulation of total ATF2 (diamonds), phosphorylated ATF2 (circles), and trkA (squares) were quantified. Retrograde (solid) and anterograde (open) axonal transport is shown. Values have been presented relative to the $6 \mathrm{hr}$ accumulation, and all values were adjusted for local synthesis. Values are means $\pm \mathrm{SD}(n=$ $3)$. The rate of accumulation was $\sim 1 \mu \mathrm{m} / \mathrm{sec}$ for all proteins measured.

functional relationship between NGF actions and ATF2 activation. However, ATF2 was also enriched in the RET/IB4 population of cells, suggesting that GDNF actions may also be mediated through this signaling pathway. The capacity of NGF to regulate the retrograde axonal transport and phosphorylation status of ATF2 is striking and provides a means of modulating sensory neuron phenotype from a site remote from the cell body. Schmied et al. (1993) and Povelones et al. (1997) have shown that proteins containing an NLS are conveyed from axon to nucleus. ATF2 has a sequence motif homologous to the NLS described by Schmeid et al. (1993). We therefore propose that the NGF-dependent modulation of retrograde axonal transport of ATF2 that we have observed is translocated to the nucleus. On reaching the nucleus the modified ratio of active to inactive ATF2 may have direct effects as well as impinging on the binding and activation of other transcription factors at CRE and AP-1 sites. NGF-dependent regulation of gene expression may therefore be the result of the alterations in the levels of phosphorylated ATF2 interfering with the competing regulatory activities of factors such as CREB and fos. This, in turn, could lead to activation of alternative programs of gene expression. For example, the absence of NGF may be perceived as a signal of axotomy, and consequently genes directing nerve regeneration could be switched on. For neurons with long axons, axonal transport of a transcription factor may be an important means of integrating distant target-derived instructions with local signaling at the cell body.

\section{REFERENCES}

Averill S, McMahon SB, Clary DO, Reichardt LF, Priestley JV (1995) Immunocytochemical localization of trkA receptors in chemically identified subgroups of adult rat sensory neurons. Eur J Neurosci $7: 1484-1494$

Averill S, Fernyhough P, Delcroix J-D, Tomlinson DR, Priestley JV (1998) Immunocytochemical analysis of MAP kinases and target transcription factors in rat dorsal root ganglia and sciatic nerve. Soc Neurosci Abstr 24:1294.

Bennett DL, Michael GJ, Ramachandran N, Munson JB, Averill S, Yan Q, McMahon SB, Priestley JV (1998) A distinct subgroup of small DRG cells express GDNF receptor components and GDNF is protective for these neurons after nerve injury. J Neurosci 18:3059-3072.

Bhattacharyya A, Watson FL, Bradlee TA, Pomeroy SL, Stiles CD, Segal RA (1997) Trk receptors function as rapid retrograde signal carriers in the adult nervous system. J Neurosci 17:7007-7016.

Bonni A, Greenberg ME (1997) Neurotrophin regulation of gene expression. Can J Neurol Sci 24:272-283.

Casaccia-Bonnefil P, Carter BD, Dobrowsky RT, Chao MV (1996)
Death of oligodendrocytes mediated by the interaction of nerve growth factor with its receptor p75. Nature 383:716-719.

Chao MV, Hempstead BL (1995) p75 and Trk: a two-receptor system. Trends Neurosci 18:321-326.

Crepieux P, Kwon H, Leclerc N, Spencer W, Richard S, Lin R, Hiscott J (1997) I kappaB alpha physically interacts with a cytoskeletonassociated protein through its signal response domain. Mol Cell Biol 17:7375-7385.

Crino PB, Eberwine J (1996) Molecular characterization of the dendritic growth cone: regulated mRNA transport and local protein synthesis. Neuron 17:1173-1187.

Crino PB, Khodakhah K, Becker K, Ginsberg S, Hemby S, Eberwine J (1998) Presence and phosphorylation of transcription factors in developing dendrites. Proc Natl Acad Sci USA 95:2313-2318.

Curtis R, DiStefano PS (1994) Neurotrophic factors, retrograde axonal transport and cell signalling. Trends Cell Biol 4:383-386.

Dechant G, Barde YA (1997) Signalling through the neurotrophin receptor p75 NTR . Curr Opin Neurobiol 7:413-418.

Delcroix J-D, Tomlinson DR, Fernyhough P (1997) Diabetes and axotomy-induced deficits in retrograde axonal transport of nerve growth factor correlate with decreased levels of $\mathrm{p}^{75 \mathrm{LNTR}}$ protein in lumbar dorsal root ganglia. Mol Brain Res 51:82-90.

Deshmukh M, Johnson Jr EM (1997) Programmed cell death in neurons: focus on the pathway of nerve growth factor deprivation-induced death of sympathetic neurons. Mol Pharmacol 51:897-906.

Ehlers MD, Kaplan DR, Price DL, Koliatsos VE (1995) NGFstimulated retrograde transport of trkA in the mammalian nervous system. J Cell Biol 130:149-156.

Eilers A, Whitfield J, Babij C, Rubin LL, Ham J (1998) Role of the Jun kinase pathway in the regulation of c-Jun expression and apoptosis in sympathetic neurons. J Neurosci 18:1713-1724.

Fernyhough P, Gallgher A, Averill S, Priestley JV, Hounsom L, Patel J, Tomlinson DR (1999) Aberrant neurofilament phosphorylation in sensory neurons of rats with diabetic neuropathy. Diabetes 48:881-889.

Finkbeiner S, Tavazoie SF, Maloratsky A, Jacobs KM, Harris KM, Greenberg ME (1997) CREB: A major mediator of neuronal neurotrophin responses. Neuron 19:1031-1047.

Georgopoulos K, Morgan BA, Moore DD (1992) Functionally distinct isoforms of the CRE-BP DNA binding protein mediate activity of a T-Cell specific enhancer. Mol Cell Biol 12:747-757.

Giasson BI, Mushynski WE (1997) Study of proline-directed protein kinases involved in phosphorylation of the heavy neurofilament subunit. J Neurosci 17:9466-9472.

Hai T, Liu F, Coukos WJ, Green MR (1989) Transcription factor ATF cDNA clones: an extensive family of leucine zipper proteins able to selectively form DNA-binding heterodimers. Genes Dev 3:2083-2090.

Johansson SO, Crouch MF, Hendry IA (1995) Retrograde axonal transport of signal transduction proteins in rat sciatic nerve. Brain Res 690:55-63.

Kaplan DR, Miller FD (1997) Signal transduction by the neurotrophin receptors. Curr Opin Cell Biol 9:213-221.

Kiebler MA, Hemraj I, Verkade P, Kohrmann M, Fortes P, Marion RM, Ortin J, Dotti CG (1999) The mammalian staufen protein localizes to the somatodendritic domain of cultured hippocampal neurons: implications for its involvement in mRNA transport. J Neurosci 19:288-297.

Livingstone K, Patel G, Jones N (1995) ATF-2 contains a phosphorylation-dependent transcriptional activation domain. EMBO J 14:1785-1797.

Loeb DM, Tsao H, Cobb MH, Greene LA (1992) NGF and other growth factors induce an association between ERK1 and the NGF receptor, gp140 ${ }^{\text {prototrk }}$. Neuron 9:1053-1065.

Minden A, Lin A, McMahon M, Lange-Carter C, Derijard B, Davis RJ, Johnson GL, Karin M (1994) Differential activation of ERK and JNK mitogen-activated protein kinases by raf-1 and MEKK. Science 266:1719-1723.

Nagata K, Puls A, Futter G, Aspenstrom P, Schaefer E, Nakata T, Hirokawa N, Hall A (1998) The MAP kinase kinase kinase MLK2 co-localizes with activated JNK along microtubules and associates with kinesin superfamily motor KIF3. EMBO J 17:149-158.

O'Neill LA, Kaltschmidt C (1997) NF-kappa B: a crucial transcription factor for glial and neuronal cell function. Trends Neurosci 20:252-258.

Olink-Coux M, Hollenbeck PJ (1996) Localization and active transport of mRNA in axons of sympathetic neurons in culture. J Neurosci 16:1346-1358. 
Povelones M, Tran K, Thanos D, Ambron RT (1997) An NF-KB-like transcription factor in axoplasm is rapidly inactivated after nerve injury in Aplysia. J Neurosci 17:4915-4920.

Priestley JV (1997) Immunocytochemical techniques for the study of the nervous system. In: Neurochemistry: a practical approach (Bachelard H, Turner A, eds), pp 71-120. Oxford: Oxford UP.

Quinn JP, Mendelson SC, Paterson JM, McAllister J, Morrison CF (1995) Transcriptional control of neuropeptide gene expression in sensory neurons, using the preprotachykinin-A gene as a model. Can J Physiol Pharmacol 73:957-962.

Rabizadeh S, Oh J, Zhong LT, Yang J, Bitler CM, Butcher LL, Bredesen DE (1993) Induction of apoptosis by the low-affinity NGF receptor. Science 261:345-348.

Schmied R, Huang C-C, Zhang X-P, Ambron DA, Ambron RT (1993) Endogenous axoplasmic proteins and proteins containing nuclear localization signal sequences use the retrograde axonal transport/nuclear import pathway in Aplysia neurons. J Neurosci 13:4064-4071.

Senger DL, Campenot RB (1997) Rapid retrograde tyrosine phosphorylation of trkA and other proteins in rat sympathetic neurons in compartmented cultures. J Cell Biol 138:411-421.

Sgambato V, Vanhoutte P, Pagès C, Rogard M, Hipskind R, Besson MJ, Caboche J (1998) In vivo expression and regulation of Elk-1, a target of the extracellular-regulated kinase signaling pathway, in the adult rat brain. J Neurosci 18:214-226.

Snider WD, McMahon SB (1998) Tackling pain at the source: new ideas about nociceptors. Neuron 20:629-632.

Su B, Karin M (1996) Mitogen-activated protein kinase cascades and regulation of gene expression. Curr Opin Immunol 8:402-411.

Trembleau A, Morales M, Bloom FE (1996) Differential compartmentalization of vasopressin messenger RNA and neuropeptide within the rat hypothalomo-neurohypophysial axonal tracts: light and electron microscope evidence. Neuroscience 70:113-125.

Vetter ML, Martin-Zanca D, Parada LF, Bishop JM, Kaplan DR (1991) Nerve growth factor rapidly stimulates tyrosine phosphorylation of phospholipase-gamma1 by a kinase activity associated with the product of the trk proto-oncogene. Proc Natl Acad Sci USA 88:5650-5654.

Virdee K, Bannister AJ, Hunt SP, Tolkovsky AM (1997) Comparison between the timing of JNK activation, c-Jun phosphorylation, and onset of death commitment in sympathetic neurones. J Neurochem 69:550-561.

Walton M, Woodgate AM, Sirimanne E, Gluckman P, Dragunow M (1998) ATF-2 phosphorylation in apoptotic neuronal death. Mol Brain Res 63:198-204.

Whitmarsh AJ, Davis RJ (1996) Transcription factor AP-1 regulation by mitogen-activated protein kinase signal transduction pathways. J Mol Med 74:589-607.

Xia Z, Dickens M, Raingeaud J, Davis RJ, Greenberg ME (1995) Opposing effects of ERK and JNK-p38 MAP kinases on apoptosis. Science 270:1326-1331.

Xing J, Kornhauser JM, Xia ZG, Thiele EA, Greenberg ME (1998) Nerve growth factor activates extracellular signal-regulated kinase and p38 mitogen-activated protein kinase pathways to stimulate CREB serine 133 phosphorylation. Mol Cell Biol 18:1946-1955. 